\section{Inter-Simple Sequence Repeat-Restriction Fragment Length Poly- morphisms for DNA Fingerprinting}

\author{
BioTechniques 34:942-944 (May 2003)
}

As part of this laboratory's honeybee genetics and breeding program, DNA markers are needed for uses such as the identification of populations and species and marker-assisted breeding. In particular, DNA markers are needed to discriminate Varroa-mite-resistant Russian honey bees, imported from fareastern Russia, and their offspring (1), from the other honey bees found in the USA. I tried RAPDs, but they were often unrepeatable. AFLPs require an undesirably large amount of preparation effort for each sample. Microsatellites have been useful for other studies in honey bees $(2,3)$, but for this purpose there is inadequate variation with the primer pairs available. Microsatelliteprimed PCR involves the amplification of DNA using a single primer composed of a microsatellite sequence (simple sequence repeat; SSR) with 1-3 selective, often degenerate, nucleotides at the end. The amplified

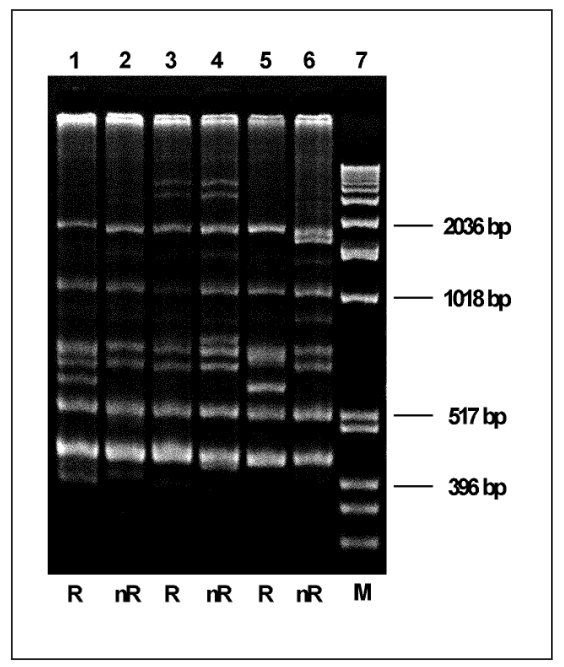

Figure 1. Elchrom gel electrophoresis of ISSR PCR products from three Russian (R) and three Italian-ancestry $(\mathrm{nR})$ honey bees using primer $(\mathbf{A C})_{8} \mathbf{G}$. Numbers on the right side are molecular weights in base pairs for the closest bands in lane M, 1-kb DNA ladder (Invitrogen). fragments are termed inter-simple sequence repeats (4). The first report of ISSRs by Zietkiewicz et al. (5) discussed several mammals, other vertebrates, plants, and E. coli. Since then, ISSRs have been reported mostly from studies in plants, particularly where inadequate variation or reproducibility were available with other methods [e.g., primer pairs in Ipomoea (4) and in Fragaria linkage analysis (6), cocoa germplasm characterization (7), intersimple sequence repeat (ISSR) inheritance in citrus (8), and classifying rice germplasm (9)]. However, ISSRs have also been used to study variation in aphids, a mosquito, and a rotifer (10); a rice pest insect (11); the silkworm (12); and corals (13). I also successfully amplified ISSR fragments from Varroa mites and Hawaiian Drosophila (data not reported). This indicates that ISSRs and ISSR-RFLPs should be detectable in any organism where DNA markers can be detected. Here I describe a new method to increase the amount of detectable DNA variation by digesting ISSRs with restriction enzymes to produce ISSR-RFLPs. The digested amplification products are detected using ethidium bromide after electrophoresis.

This is a novel combination of procedures and is an improvement over just ISSRs because restriction enzyme digestion of ISSR fragments allows the detection of significant amounts of additional variation using a more repeatable and reproducible procedure. This would be particularly useful in cases where inadequate amounts of detectable genetic variation are available using ISSRs or other methods or where more variation is desired from a limited number of ISSR primers. Detection of RFLPs in PCR-amplified DNA using ethidium bromide eliminates the requirements for Southern transfers, unique probes for detection, and labeled probes or primers. This simplifies detection and reduces costs.

Genomic DNA from the thorax of a single worker honey bee, Apis mellifera L., from a colony, with each colony from a different source, was extracted with $400 \mu \mathrm{L} 10 \%$ Chelex $^{\circledR}$ resin (14). SSR primers were purchased from the Oligonucleotide Synthesis Laboratory, NAPS Unit, University of British Columbia (Vancouver, BC, Canada). For initial evaluations of primers and DNA templates, the PCR procedure of Huang and Sun (4) was followed, but unlabeled primers were used and PCR products were detected by ethidium bromide staining after electrophoresis. Amplification was carried out in a total volume of $5 \mu \mathrm{L}$ containing $0.35 \mu \mathrm{L}$ Chelex extract template DNA, $0.21 \mu \mathrm{M}$ primer, $0.2 \mathrm{mM}$ dNTPs, $1.5 \mathrm{mM}$ $\mathrm{MgCl}_{2}, 0.5 \mathrm{U}$ Taq DNA polymerase

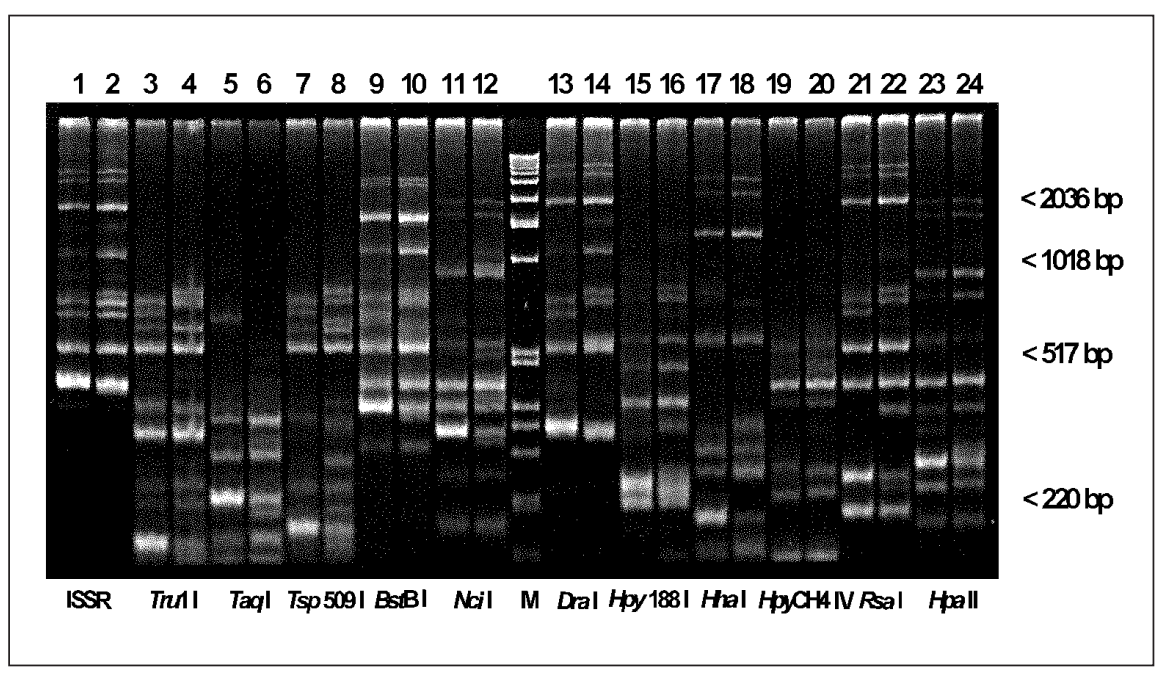

Figure 2. Elchrom gel electrophoresis of ISSR PCR products and restriction enzyme digests from one Russian and one Italian-ancestry honey bees using primer $(\mathrm{AC})_{8} \mathrm{G}$. The odd-numbered lane of each pair is from aliquots from one PCR amplification of template DNA from one Russian honey bee, and the even-numbered lane in each pair is from aliquots from one amplification from one Italian-ancestry honey bee. Numbers on the right side are molecular weights in base pairs for the closest bands in lane M, 1-kb DNA ladder (Invitrogen). 
(Invitrogen, Carlsbad, CA, USA), and $1 \times$ PCR buffer containing $20 \mathrm{mM}$ Tris$\mathrm{HCl}(\mathrm{pH} \mathrm{8.4)}$ and $50 \mathrm{mM} \mathrm{KCl}$. PCR was performed in a PTC- $100^{\mathrm{TM}}$ thermal cycler (MJ Research, Waltham, MA, USA) with a heated lid, using the following cycle profile: 1 cycle at $94^{\circ} \mathrm{C}$ for $4 \mathrm{~min}$, followed by 34 cycles of $94^{\circ} \mathrm{C}$ for $45 \mathrm{~s}, 51^{\circ} \mathrm{C}$ for $45 \mathrm{~s}, 72^{\circ} \mathrm{C}$ for $1.5 \mathrm{~min}$, and a final 7 -min extension at $72^{\circ} \mathrm{C}$. Primers often required individual optimization for concentrations of primer, dNTP, and Taq DNA polymerase. Following PCR, each amplification, along with $2 \mu \mathrm{L}$ Elchrom loading buffer, was loaded into a precast $6 \%$ Poly(NAT) ${ }^{\circledR}$ horizontal slab gel (similar to acrylamide) in $30 \mathrm{mM}$ TAE in an Elchrom SEA $2000^{\circledR}$ electrophoresis unit (Elchrom, Cham, Switzerland) and electrophoresed for 1 $\mathrm{h}$ at $105 \mathrm{~V}$. For data recording, each gel was removed from the plastic backing, agitated for $40 \mathrm{~min}$ in $0.5 \mu \mathrm{g} / \mathrm{mL}$ ethid- ium bromide solution, and photographed on a UV transilluminator with a Kodak ${ }^{\circledR}$ EDAS 290 (Eastman Kodak, Rochester, NY, USA). For restriction enzyme digestion, PCR amplification was carried out in a total volume of $75 \mu \mathrm{L}$ at the same reagent ratios as the $5-\mu \mathrm{L}$ reactions. A $4-\mu \mathrm{L}$ aliquot from each amplification was analyzed to see if the PCR amplifications were successful. If successful, $5-\mu \mathrm{L}$ aliquots from the same amplification for each honey bee were digested with restriction enzymes (RE) (New England Biolabs, Beverly, MA, USA) as follows: 5 $\mu \mathrm{L}$ PCR amplification, $1 \mu \mathrm{g}$ BSA if required, $1 \mu \mathrm{L} 10 \times$ RE buffer, $2.5 \mathrm{U}$ RE, water to $10 \mu \mathrm{L}$ total. Restriction enzyme digestion was for $2 \mathrm{~h}$ or overnight at the temperature specified by the manufacturer, generally $37^{\circ} \mathrm{C}$. Two microliters of Elchrom loading buffer were added to each digestion, and they were gel analyzed as above, except that electrophoresis was carried out for 50 min to avoid running small fragments off the gel.

Figure 1 shows the ISSR banding patterns produced by UBC primer 827 , $(\mathrm{AC})_{8} \mathrm{G}$, with three Russian (R) and three Italian-ancestry (nR) honey bees, all from different colonies. Figure 2 shows the ISSR-RFLP bands from restriction enzyme digestion of the ISSR bands in lanes 1 and 2 . The odd-numbered lanes of Figure 2 are aliquots from the same PCR amplification as lane 3 of Figure 1. The even-numbered lanes of Figure 2 are aliquots from the same PCR amplification as lane 4 of Figure 1. Therefore, all restriction fragments are from digestion of the ISSR fragments from the two PCR amplifications shown in lanes 1 and 2, and variations are not nonspecific bands or artifacts of different amplifications. While some variation among the samples is present in Figure 1, lanes 3 and 4 differ 


\section{Benchmarks}

only by the presence of two additional lighter bands in lane 4 . When the ISSR bands from these two samples are digested with 11 restriction enzymes, further variation is detectable between the pairs for all restriction enzymes (Figure 2). Thus, restriction enzyme digestion of these ISSR bands detects much additional DNA variation specific to these two bees without further PCR optimization for new primers.

With ethidium bromide detection, 2-6 prominent ISSR fragments and several fainter fragments were usually found when many different ISSR primers were tested (data not reported). Most of the fragments were in the 400-2000 bp range compared to the $50-500$ bp range reported by Huang and Sun (4). For most primers, the patterns of the prominent fragments were much more repeatable at varying levels of template DNA than I had found with RAPDs. Several RFLPs were observed for most primer/restriction enzyme combinations. Thus restriction enzyme digestion detects much additional variation among ISSR PCR fragments.

Much of the initial effort in PCRbased studies involves optimization of the PCR conditions, and this also applies to ISSRs. Restriction enzyme digestion of ISSR bands does not require optimization for different ISSRs. Thus, much less optimization effort is required to screen additional restriction enzymes for one ISSR than is required to screen additional ISSR primers to detect an equal amount of variation. While the initial step to detect ISSRRFLPs does require large reaction PCR to amplify the ISSR bands, PCR machines are not needed for restriction enzyme digestion. Thus, much less use of PCR machines is required for ISSRRFLPs than for detection of an equal amount of ISSR variation. Effort can then be concentrated on those ISSR primers that are the most reliable and produce the most useful bands. While PCR amplifications with some ISSR primers often fail or are of uneven quality, restriction enzyme digestions of ISSR amplifications are much more reliable and repeatable.

Verification of successful PCR amplification before restriction enzyme digestion allows the researcher to avoid attempting to digest poor or failed am- plifications. Failed or poor amplifications can be repeated or modified and repeated or different samples can be substituted, minimizing waste of resources by identifying problems early in the process. This uncouples the relatively reliable process of restriction enzyme digestion from the often more problematic process of PCR, thus increasing the reliability of the final data.

For research and stock identification purposes, we needed DNA markers to distinguish Russian honey bees from other types of honey bees present in the USA. Using a different primer and four restriction enzymes, it is possible to use ISSR-RFLPs to discriminate between Russian and other honey bees (data not reported).

\section{REFERENCES}

1.Rinderer, T.E., L.I. de Guzman, G.T. Delatte, J.A. Stelzer, V.A. Lancaster, V. Kuznetsov, L. Beaman, R. Watts, and J.W. Harris. 2001. Resistance to the parasitic mite Varroa destructor in honey bees from far-eastern Russia. Apidologie 32:381-394

2.Estoup, A., M. Solignac, M. Harry, and J.M. Cornuet. 1993. Characterization of $(\mathrm{GT})_{\mathrm{n}}$ and $(\mathrm{CT})_{\mathrm{n}}$ microsatellites in two insect species: Apis mellifera and Bombus terrestris. Nucleic Acids Res. 21:1427-1431.

3.Rowe, D.J., T.E. Rinderer, J.A. Stelzer, B.P. Oldroyd, and R.H. Crozier. 1997. Seven polymorphic microsatellite loci in honey bees (Apis mellifera). Insectes Sociaux 44:85-93.

4.Huang, J. and M. Sun. 2000. Fluorescein PAGE analysis of microsatellite-primed PCR: a fast and efficient approach for genomic fingerprinting. BioTechniques 28:1068-1072

5.Zietkiewicz, E., A. Rafalski, and D. Labuda. 1994. Genome fingerprinting by simplesequence repeat (SSR)-anchored polymerase chain reaction amplification. Genomics 20:176-183.

6.Cekic, C., N.H. Battey, and M.J. Wilkinson. 2001. The potential of ISSR-PCR primer-pair combinations for genetic linkage analysis using the seasonal flowering locus in Fragaria as a model. Theor. Appl. Genet. 103:540-546.

7.Charters, Y.M. and M.J. Wilkinson. 2000. The use of self-pollinated progenies as "ingroups" for the genetic characterization of cocoa germplasm. Theor. Appl. Genet. 100:160166 .

8.Fang, D.Q. and M.L. Roose. 1999. Inheritance of intersimple sequence repeat markers in citrus. J. Hered. 90:247-249.

9.Virk, P.S., J. Zhu, H.J. Newbury, G.J. Bryan, M.T. Jackson, and B.V. Ford-Lloyd. 2000. Effectiveness of different classes of molecular marker for classifying and revealing variation in rice (Oryza sativa) germplasm. Euphytica 112:275-284.

10.Abbot, P. 2001. Individual and population variation in invertebrates revealed by intersimple sequence repeats (ISSRs). 4 p. Journal of Insect Science 1.8.online: insectscience. org $/ 1.8$

11.Kumar, L.S., A.S. Sawant, V.S. Gupta, and P.K. Ranjekar. 2001. Comparative analysis of genetic diversity among Indian populations of Scirpophaga incertulas by ISSR-PCR and RAPD-PCR. Biochem. Genet. 39:297-309.

12.Reddy, K.D., J. Nagaraju, and E.G. Abraham. 1999. Genetic characterization of the silkworm Bombyx mori by simple sequence repeat (SSR)-anchored PCR. Heredity 83:681-687.

13.Snell, T.L. and M.A. Coffroth. 1999. Use of intersimple sequence repeats in analyzing intra- and interspecific variability in scleractinian corals. Amer. Zool. 39:122A.

14.Walsh, P.S., D.A. Metzger, and R. Higuchi. 1991. Chelex 100 as a medium for simple extraction of DNA for PCR-based typing from forensic material. BioTechniques 10:506-513.

I thank Rachel Watts and Tony Stelzer for technical assistance. I thank Jay D. Evans, Yong-Bao Pan, and Sonja J. Scheffer for reviews of an earlier version of this manuscript. In cooperation with the Louisiana Agricultural Experiment Station. Address correspondence to Dr. H. Allen Sylvester, Honey-Bee Breeding, Genetics \& Physiology Laboratory, 1157 Ben Hur Road, Baton Rouge, LA 70820, USA. e-mail: asylvester@ars.usda.gov

Received 5 June 2002; accepted 6 March 2003.

H. Allen Sylvester

United States Department of Agriculture Baton Rouge, LA, USA 